Les travaux furent d'abord présidés par le regretté Professeur Georges Smets.

Le Président du Centre est actuellement le Professeur Armand Abel.

Le Professeur Luc de Heusch, Rapporteur des débats, est responsable de l'édition des Annales du Centre. Les deux premiers volumes ont paru en 1962 .

Tome I. 'Le pouvoir et le sacré' - I 8 r p., I 80 frs belges.

Tome II. 'Religions de salut' - 228 p., 200 frs belges.

Ces deux volumes peuvent être acquis au Service des Editions de l'Institut de Sociologie, Parc Léopold, rue Belliard, Bruxelles 4.

\title{
Le Centre Africain des Sciences Humaines Appliquées (C.A.S.H.A.)
}

L.E Centre Africain des Sciences Humaines Appliquées, fondé en Avril i961, a pour objet - d'entreprendre et de promouvoir . . . dans tous domaines relevant des sciences humaines, des recherches destinées à faire progresser l'étude des problèmes humains de la vie sociale et professionnelle, et notamment ceux de sous-développement'. Le C.A.S.H.A., tout en développant ses activités propres, coopère au maximum sur tous les plans avecles organismes de recherche nationaux et internationaux et notamment avec les universités. Les programmes de recherches du C.A.S.H.A. comprennent des études de l'organisation urbaine et structures sociales en Algérie, de l'Algérie des bidonvilles, et des attitudes du sous-prolétariat algérien à l'égard de la société urbaine. I Le siège central est établi à Aix-en-Provence (28 Avenue Victor-Hugo): Alger et Dakar constituent les bases de travail en Afrique.

\section{Theal's 'History of South Africa'}

A NEw reprint of G. McCall Theal's complete History of South Africa is at present being prepared in Cape Town. The work will be published in eleven volumes by photographic reprint from the latest and best edition. All separate and folding maps will be reproduced in their original colours. Pre-publication price will be $\mathrm{R} 50\left(\AA_{25}\right)$ for the complete set, afterwards $\mathrm{R} 65$ ( $£_{32}$ 2. Ios.). The edition will probably be limited to 500 copies. A facsimile reprint of Theal's Records of South East Africa in nine volumes is also in preparation, price $\mathrm{R} 70(£ 35)$. Orders for both these publications may be placed with Messrs. W. \& G. Foyle, 1 2-1 4 Church Street, Cape Town.

\section{A Population Map of Kenya, 1962}

THE Department of Geography of the Royal College, Nairobi, a constituent college of the University of East Africa, has published a map showing the distribution of the population of Kenya, based on the census taken on the night of I5-16 August 1962. 'The map is in two sheets at a scale of one to one million (approximately sixteen miles to one inch). Population in rural areas is shown by dots in two sizes, the smaller representing 200 and the larger 1,000 persons. In pastoral areas the population is shown as spread over the grazing areas. The limits of Nairobi and Mombasa are shown and the population represented by proportional circles. The area of Karasuk is administered by Uganda and was not included in the census. The representation of the distribution of population in this detail permits comparison with rainfall and other aspects of the natural environment and with economic and social conditions. The Economics and Statistics Division of the Treasury, the Survey of Kenya, District Commissioners, and the Mines and Geological Department assisted in the preparation of the map. Copies may be purchased at ios. the set of two sheets from the E.S.A. Bookshop, P.O. Box 30167 , Nairobi; postage is $3 s .3 d$. for East Africa and the Commonwealth and 5s. elsewhere. Copies may also be obtained from Edward Stanford Ltd., I 2-I 4 Long Acre, London, W.C. 2 .

Voir les comptes rendus, pp. 70-7r. 